\title{
Detailed Internal Structure and Along-Strike Variability of the Core of a Plate Boundary Fault: The
}

Highland Boundary Fault, Scotland

西

\section{Abbreviated Title: Internal Fault Core Structure of the HBF}

. Lucy McKay ${ }^{1 *}$, Zoe K. Shipton ${ }^{1}$, Rebecca J. Lunn ${ }^{1}$, Billy Andrews ${ }^{1}$, Timothy D. Raub ${ }^{2}$ \& Adrian J. Boyce ${ }^{3}$

${ }^{1}$ Department of Civil and Environmental Engineering, University of Strathclyde, 75 Montrose Street, 9 Glasgow G1 1XJ, UK

2 Department of Earth Sciences, University of St. Andrews, North Street, St. Andrews KY16 9AL, UK ${ }^{3}$ Scottish Universities Environmental Research Centre, East Kilbride G75 0QF, UK

* Corresponding author (e-mail: lucy.mckay@strath.ac.uk)

\section{ABSTRACT}

The Highland Boundary fault near Stonehaven, NE Scotland, provides a rare opportunity to study the internal fault structure of a well-exposed, along-strike section of an ancient plate boundary fault. As in many plate boundaries, serpentinite juxtaposes quartzo-feldspathic crustal rocks of distinct terranes. We report, for the first time, the complex internal structure of the Highland Boundary fault core, comprised of four structurally and chemically distinct clay-rich units that remain unmixed. Despite the evidence for internal strain, relatively intact clasts of wall rock and microfossils are preserved within the clay. The fault core clay minerology is consistent with a shallow, low temperature authigenesis derived from shearenhanced chemical reactions between wall rocks of contrasting chemistry during sinistral strike-slip. The observed structure is comparable to those of other major weak-cored plate boundaries (e.g., San Andreas fault). Through detailed mapping, we demonstrate that the internal structure of a plate boundary fault core can vary in thickness and composition along-strike over centimetre to meter length scales. 
26 Earthquake rupture mechanics critically depend on the physical properties of fault rock assemblages.

27 Therefore, models that investigate rupture propagation at active plate boundaries should incorporate, or

28 else assess tolerance and sensitivity to, variable fault core thickness and composition.

29

30 SUPPLEMENTARY MATERIAL: Further X-ray diffraction (XRD) analytical data are available at

31 https://doi.org/xxxx'. 
32 Understanding the internal structure of large faults is crucial because the chemical and mechanical

33 properties of faults control how earthquakes rupture, nucleate and propagate (e.g., Caine et al. 1996;

34 Wibberley et al. 2008; Faulkner et al. 2010). Geologists studying faults exhumed from depth have shown

35 that they are heterogeneous along-strike and down-dip at a variety of scales (Faulkner et al. 2003;

36 Heermance et al. 2003; Wibberley \& Shimamoto 2003; Kirkpatrick et al. 2008, 2018; Barth et al. 2013;

37 Lawther et al. 2016; Sosio De Rosa et al. 2018). Such internal variations in properties can influence how readily a rupture begins and terminates (Kirkpatrick \& Shipton 2009), limiting the size of an earthquake (Cohee \& Beroza 1994; Kirkpatrick et al. 2008) or the frequency of the radiated seismic energy (Ma et al. 2003; Madariaga et al. 2006) and consequently surface severity and damage (Lin et al. 2001; Heermance et al. 2003; Ma et al. 2003). Knowledge of the internal structure and rheology of seismogenic plate boundary faults is lacking as they are normally poorly exposed at the surface.

Recently, several drilling projects have been undertaken to explore how the internal structure of active plate boundary fault zones at-depth influences slip behaviour (e.g., at the San Andreas fault in California, Bradbury et al., 2011; the Alpine fault in New Zealand, Toy et al. 2015; the Japan Trench, Kirkpatrick et al. 2015; the Nankai Trough offshore Japan, Ujiie \& Kimura 2014; and the Chelungpu fault in Taiwan, Yeh et al. 2007). Scientific findings for each of these projects highlight the presence and importance of clay-rich fault rocks for influencing slip behaviour. However, drilling projects are expensive (e.g., \$25M for SAFOD at the San Andreas; Winchester 2006) and effectively sample only one or two transects across a fault, limiting the ability to capture along-strike variability in fault zone properties. In contrast, the Highland Boundary fault (HBF), NE Scotland, provides a rare opportunity to study the internal fault structure of a well-exposed, along-strike section of a major plate boundary fault. The HBF extends for $>240 \mathrm{~km}$ along-strike separating Dalradian meta-sediments to the north from late Silurian to Early Carboniferous volcanics and siliciclastics to the southeast (Tanner 2008; Fig. 1). This study uses a 
57 field-based approach to characterise the along-strike variability in the internal structure of the HBF using 58 an exceptional $560 \mathrm{~m}$ along-strike exposure of the fault near Stonehaven, NE Scotland. Whilst the HBF is

59 well-characterised in terms of its regional tectonic importance (e.g., Tanner 2008), the only studies

60 discussing mineralisation of the fault zone focus on the wall rocks (e.g., Parnell et al. 2000; Elmore et al.

612002 ) and do not address the internal fault zone structure.

62

63 The internal structure of a fault is typically comprised of a high-strain fault core bounded by a deformed damage zone. In turn, the fault core is surrounded by undeformed host rock (Chester \& Logan 1986; Caine et al. 1996). It may consist of a single fault core (e.g., Chester et al. 1993) or multiple anastomosing fault cores that link and entrain lenses of fractured host rock between the branches (e.g., Faulkner et al. 2003). The fault core, which can range from a few centimetres up to tens of metres wide, accommodates most of the fault slip and consists of localised slip zones containing fault rocks such as clay-rich gouge, breccia or cataclasites (Faulkner et al. 2010). Few published data describe the spatial variation in fault core thickness and composition within a single fault (Barth et al. 2013; Lawther et al. 2016; Kirkpatrick et al. 2018; Sosio De Rosa et al. 2018). The damage zone, which can reach several hundred meters wide, may consist of fractured host rocks, subsidiary faults, small-displacement subsidiary slip surfaces, veins and folding at all scales (Faulkner et al., 2010).

In this study we present the first field observations of the internal structure and fault rock lithologies of the $\mathrm{HBF}$, and show that they are comparable to other major weak-cored plate boundaries such as the San Andreas fault in California. By dissecting the physical and chemical properties of the fault (e.g., thickness, fault structures and mineralogy) we demonstrate the Stonehaven section of the Highland Boundary fault core is internally composed of four distinct structurally and mineralogically variable clay-rich units that vary in thickness along-strike over different length scales. As well as contributing to the understanding of

81 the sequence of events at the Highland Boundary fault system, these observations of variable along-strike 
82 fault core internal structure, composition and thickness have implications for modelling earthquake

83 ruptures at active plate boundaries.

84

85 GEOLOGICAL SETTING

86 The HBF is a mature, ancient plate boundary fault with a long and complex history. Today, the remarkably

87 straight surface trace extends for over $240 \mathrm{~km}$ NE to SW across Scotland, with possible along-strike extension into western Ireland (Chew 2003; Tanner 2008). The fault separates two distinct geological terranes (Fig. 1a): Neoproterozoic to Cambrian, crustal, quartzo-feldspathic metasedimentary rocks (Dalradian Supergroup) of the Grampian terrane to the north from Lower Devonian, volcano-sedimentary rocks of the Midland Valley terrane (e.g., Stonehaven Group) to the south. The easternmost exposures of the Dalradian near Stonehaven experienced low pressure greenschist facies metamorphism (0.4 to 0.55 GPa) with peak temperatures of c. $375^{\circ} \mathrm{C}$ (Vorhie \& Ague 2011). The maximum burial depth of the

94 Stonehaven group was 3-5 km as determined from vitrinite reflectance (Monaghan 2014). Adjacent to the 95 fault near Stonehaven (Fig. 1b), intermittent serpentinite exposures with impersistent low-alteration zones represent the dismembered Highland Border Ophiolite (see Leslie, 2009; Henderson et al., 2009 for detailed reviews). Such juxtaposition of quartzo-feldspathic crustal rocks with a serpentinite zone (Fig. 2) has been observed along active plate boundary faults (e.g., sections of the San Andreas fault in California [Moore \& Rymer 2012] and the Alpine fault in New Zealand [Barth et al. 2013]) making the HBF a potential field analogue for the internal structure of these plate boundaries.

The HBF is considered to have been active during two events of the Caledonian Orogeny: the early Ordovician Grampian Orogeny (480 to $460 \mathrm{Ma}$ ) and the mid-Devonian Acadian Orogeny (420 to $390 \mathrm{Ma}$ )

104 (Chew \& Strachan 2014). Early fault motion was believed to be reverse, inheriting the subduction 105 interface and emplacing the Highland Border Ophiolite immediately prior to the Grampian Orogeny 106 (Ramsay 1962; Chew et al. 2010). The Highland Border Ophiolite is a mixture of both collisional (Penrose) 
107 type sequences (Chew et al. 2010) and Ligurian-type ophiolites, including seafloor supporting latest stages

108 of Dalradian sedimentation in an extensional ocean-continent transition environment (Henderson et al.

109 2009; Leslie 2009; Dilek \& Furnes 2014). It probably also incorporates more allochthonous ocean crust,

110 especially proximal to the HBF zone (Chew et al. 2010; Chew \& Strachan 2014). Overprinting by Grampian

111 metamorphism and deformation occurred ca. 465 to $461 \mathrm{Ma}$ (Viete et al. 2013). Following the Grampian

112 Orogeny, the continental collision of Laurentia with Avalonia was accommodated by partitioned

113 transpressive, sinistral strike-slip movement on the HBF and related faults (McCarthy et al. 2015) during

114 the Acadian Orogeny ca. 420 Ma (Chew \& Strachan 2014). The magnitude of strike-slip displacement is

115 debated. Based on palaeogeographical reconstructions and detrital zircon data from both the hangingwall

116 and footwall of the fault, Dewey \& Strachan (2003) and Cawood et al. (2012) support significant sinistral

117 offset of up to several hundreds of kilometres; whereas, Tanner (2008) compiles the case for an

118 alternative minimum offset of $<30 \mathrm{~km}$. The HBF was probably reactivated during late Acadian orogenic

119 collapse as a result of regional crustal extension (Chew \& Stillman 2009; Mendum \& Noble 2010). Other

120 terrane-bounding, crustal-scale Caledonian faults in Scotland were reactivated with dextral and normal

121 offset in the Mesozoic during North Sea extension and in the Cenozoic as Scotland exhumed regionally on

122 the flanks of North Atlantic opening (e.g., Le Breton et al. 2013). It would not be surprising if the HBF

123 accommodated minor motion at these younger ages.

124

125 STRUCTURAL FRAMEWORK

126 The HBF near Stonehaven is marked by a relatively straight, steep (dip: $66 \pm 7^{\circ} ; n=70$ ), north-west dipping

127 contact (strike: $059 \pm 8^{\circ} ; n=70$ ) between the fault core and Highland Border Ophiolite (footwall damage

128 zone) (Fig. 2a). A major splay of unknown offset, and with no development of clay gouge, is observed

129 trending east to west towards Garron Point (Fig. 1b). New mapping as part of this study highlights

130 numerous small offset ( 5-10 m), sinistral and dextral strike-slip faults within the Highland Border

131 Ophiolite (footwall damage zone) towards Garron Point (Fig. 1b). Kinematic markers, primarily 
132 slickenfibres recorded on calcite mineralised slip surfaces, enable these faults to be grouped into one

133 dextral and two sinistral sets that are subdivided based on orientation with respect to the mean HBF (Fig.

$1342 \mathrm{c})$. The dextral set has a mean strike of $144 \pm 18^{\circ}(n=20)$ and a north-easterly dip of $77 \pm 11^{\circ}(n=20)$

135 developing $\sim 80^{\circ}$ anticlockwise from the mean HBF. The first sinistral set has a mean strike of $038 \pm 11^{\circ}$

$136(n=12)$ and a north-westerly dip of $67 \pm 19^{\circ}(n=12)$ developing $\sim 19^{\circ}$ anticlockwise from the mean HBF. The

137 second sinistral set has a mean strike of $92 \pm 24^{\circ}(n=16)$ and a northernly dip of $69 \pm 14^{\circ}(n=18)$ developing

$138 \sim 30^{\circ}$ clockwise from the mean HBF. Several small-scale $(<1 \mathrm{~m}$ offset) thrust faults are also observed below

139 the scale of mapping. In places, these thrust faults sole onto strike-slip faults. No consistent cross-cutting

140 relationships are observed, suggesting they all formed concurrently. If these faults represent Reidel shears

141 to the main fault, they fit with sinistral strike-slip motion on the HBF (Fig. 2d). We see no field-scale

142 evidence for late-stage dextral or normal offset that would be consistent with Mesozoic and Cenozoic

143 reactivation.

145 METHODS

146 To characterise the internal structure of the HBF and its along-strike variability we collected six across-

147 fault transects (structural logs) perpendicular to the fault plane (locations given in Fig. 1b). All logs except

148 Log 3 mapped the fault core. Log 3 investigated the folding and maximum extent of the Dalradian damage

149 zone. To expose the fault core for mapping and sampling, the shingle below the high tide mark was

150 scraped back using spades and trowels along as linear a transect as possible, avoiding large boulders. The

151 shingle was subsequently replaced after sample collection to maximise the conservation of this SSSI (Site

152 of Special Scientific Interest). A series of eighteen logs $1 \mathrm{~m}$ apart were also collected between Logs 5 and 6

153 to capture the smaller, metre-scale variability of the fault core. We describe the fault breccias following

154 the classification of Woodcock \& Mort (2008). 
156 Twelve samples from Log 4 [grid reference NO 388914 787493] were analysed by X-ray diffraction (XRD).

157 These include one representative sample from each of the three fault core units, two samples of the clasts within the red foliated chaotic breccia, six damage zone samples from the Highland Border Ophiolite and Dalradian and one from the Dalradian host rock. 10 g of each sample was oven dried before grinding to a fine powder with a mean particle diameter of 5 to 10 microns before analysis. Randomly-oriented samples were analysed for whole-rock mineralogy. Highland Border Ophiolite and Dalradian powders were analysed using a Bruker D8 Advance Diffractometer, scanning from $5^{\circ}$ to $60^{\circ}$ at $0.02^{\circ} 2 \Theta$ step-size intervals at $40 \mathrm{kV}$ and $40 \mathrm{~mA}$ (Cu-Ka radiation). Clay powders were analysed by X-Ray Minerals Ltd. using a PANalytical X'Pert3 Diffractometer and scanned from $4.5^{\circ}$ to $75^{\circ}$ at $0.013^{\circ} 2 \Theta$ step-size intervals at $40 \mathrm{kV}$ and $40 \mathrm{~mA}$ (Cu-Ka radiation). An intensity-based quantification analysis was performed where the maximum intensity of each mineral identified was measured and compared to a standard intensity for a pure sample of that mineral. The results were normalised to $100 \%$ based on the assumption that the complete mineral content of the sample is accounted for in the diffractogram. Additionally, the $<2 \mu \mathrm{m}$ fraction was separated, to identify clay mineral phases following Moore \& Reynolds (1997). Samples were placed on orientated mounts and analysed before and after treatment with ethylene glycol and heating to $380^{\circ} \mathrm{C}$ and $550^{\circ} \mathrm{C}$ using a Philips PW1730 Generator Diffractometer. Air-dried and glycolated samples were scanned from $3^{\circ}$ to $35^{\circ}$ at $0.05^{\circ} 2 \Theta$ step-size intervals at $40 \mathrm{kV}$ and $40 \mathrm{~mA}$ (Cu-Ka radiation). The untreated sample was also analysed between 24 to $27^{\circ}$ at $0.02^{\circ} 2 \Theta$ step-size intervals to further define kaolinite and chlorite peaks. Chlorite, illite, and mixed-layer illite-smectite determination was based on the comparison between air-dried and glycolated samples and a peak

177 intensity quantification process. Specific peak widths indicate clay crystallinity. Relative intensities of the 178 chlorite 001 and 003 peaks determined Fe occupancy in the six octahedral sites. 
181 The internal structure of the HBF can be described as a single high-strain fault core bounded by damage

182 zones of contrasting lithology. From south to north in an across-fault transect, the HBF consists of: (1) a

183 footwall damage zone (FW DZ) comprising faulted and veined metabasalt and serpentinite sequences of the Highland Border Ophiolite; (2) a structurally and lithologically variable fault core (FC) comprising four distinct units, and; (3) a hangingwall damage zone (HW DZ) developed in chlorite- to biotite-grade Dalradian metasedimentary rocks (Fig. 3).

The footwall damage zone of the Highland Border Ophiolite is characterised by three distinct units. In logs 1-5 the footwall damage zone adjacent to the fault core (footwall damage zone 1 ) is characterised by an intensely faulted, fractured and veined, buff coloured dolomitised serpentinite properly termed ophicarbonate. Veins in this unit are $\sim 2$ to $10 \mathrm{~cm}$ thick and are filled by multiphase carbonate including very fine-grained, massive dolomite in the centre with isopachous, sparry calcite lining the vein wall (Fig. 3d). The calcite displays a dog-toothed epitaxial texture, indicative of crack-seal growth and extensional opening mode fractures. The veins are typically aligned sub-parallel to the HBF but can be split into two distinct sets based on dip and cross-cutting relationships (set 1:062/67NW, $n=67$, crosscut by set 2: $111 / 21 N E, n=11$ ). The second unit (footwall damage zone 2), adjacent to the HBF in Log 6 , is a carbonated serpentinite displaying a chaotic network of cross-cutting calcite veins. This unit is cut by localised, subhorizontal fractures with an alteration halo (Fig. 3c). The fractures have an anastomosing, conjugate geometry comprised of curvy, cross-cutting, brittle cracks. Orange to brown, calcitic alteration halos extend $\sim 3 \mathrm{~cm}$ either side of the fractures, where the alteration is symmetrical around the aperture. The alteration follows the same geometry as the fractures and can be traced into the ophicarbonate unit. The third unit (footwall damage zone 3 ) is a fractured metabasalt lava sequence with interbedded ferruginous chert and siliceous siltstone/shale, sporadic pillow lavas and a localised shear zone with evidence of reverse motion and ductile deformation (Fig. 3b). Damage zone alteration decreases away from the HBF 
with the ophicarbonate unit displaying the most fault-related deformation (i.e., subsidiary faulting, fractures and veining).

The Dalradian north of the HBF is composed of a succession of competent (e.g., metagreywacke) and less competent (e.g., pelite) beds. Beds within the hangingwall damage zone are folded into a series of open, plunging folds (wavelength $\sim 5 \mathrm{~m}$ ) with the axial plane sub-parallel to the HBF (079/86NW; Fig. 2b), and display evidence of fault-related deformation such as alteration, subsidiary fractures and brecciation. Fault-related deformation is absent beyond approximately $45 \mathrm{~m}$. We consider this the extent of the hangingwall damage zone.

\section{FAULT CORE LITHOLOGIES}

216 The fault core, which is between 2.95 and 10.7 m thick, is comprised of four structurally and chemically

217 distinct units with sharp, fault-parallel contacts. Adjacent to the HBF, observed at Log 4 only, is a zone of 218 green foliated gouge (fault core 1a) that is relatively homogenous and free of obvious clasts (Fig. 3e). This

219 is in sharp contact with a zone of a blue gouge (fault core 1) of high plasticity (Fig. 4a). In places this blue 220 gouge unit is internally foliated, the foliations being sub-parallel to the $\operatorname{HBF}\left(070 \pm 15^{\circ} ; n=17\right)$ (Fig. $\left.4 b\right)$. Small (typically $<5 \mathrm{~cm}$ diameter), sub-rounded clasts of wall rock are observed within this unit altered to a bleached white colour. Occasionally larger, fragmented, altered clasts are observed (Fig. 5a).

Towards the hangingwall damage zone the blue gouge has a distinct fault-parallel contact with a red foliated chaotic breccia unit (fault core 2) (Fig. 4a). A localised zone of mixing (10 to $50 \mathrm{~cm}$ thick) is observed against the sharp contact, where the zone of mixing extends into both units either side of the contact (Fig. 3f, Fig 5a). This zone consists of distinct patches and stripes of red and blue clay. The foliated chaotic breccia unit has a grey silty texture with red, hematitic foliations that define a clear structural fabric. The compositional (colour) foliations are generally aligned parallel to the HBF with a mean 
orientation of $060 \pm 23^{\circ}$ ( $\left.n=101\right)$ (Fig. 4c) but anastomose and wrap around variably altered, sub-angular, centimetre-scale, metasedimentary clasts of the Dalradian. In places the foliation is internally folded (Fig. 5b). Clast size, aspect ratio and abundance increase towards the hangingwall (Fig. 4a). For example, clasts within the blue gouge have a mean long axis of $1 \mathrm{~cm}(n=8)$ and a mean aspect ratio of $1.7(n=8)$. Within the red foliated chaotic breccia, the clasts have a mean long axis of $19 \mathrm{~cm}(n=65)$ elongate parallel to the HBF and a mean aspect ratio of $2.8(n=65)$. Several clasts can be described as lens-shaped boudins with the long axis (orientation $076^{\circ}$ ) parallel to the $\mathrm{HBF}$, indicating asymmetric shear fractures parallel to the HBF (Fig. 4a).

At Logs 5 and 6 , the transition zone between the fault core and hangingwall damage zone comprises a red crackle breccia with large, fragmented, metasedimentary lenses of Dalradian up to $2.3 \mathrm{~m}$ long. Thin $(<5$ $\mathrm{cm}$ and typically $<1 \mathrm{~cm}$ ) zones of foliated clay (clay content 5 to $10 \%$ ) are observed between, and wrapping around the lenses (Fig. 5c). The clay zones are interpreted as high strain zones and can be observed cutting through some of the larger lenses. The lenses have a mean long axis of $81 \mathrm{~cm}(\mathrm{n}=32)$ and a mean aspect ratio of $3.3(n=32)$. All clasts and lenses within the fault core have a preferred orientation and are elongate in the direction parallel to the HBF with a mean apparent long axis orientation of $067 \pm$ $15^{\circ}(n=97)$ on a sub-horizontal exposure (Fig. 4d), and clasts observes to be dipping parallel to the dip of the footwall damage zone contact. The clay content generally decreases away from the HBF with a concomitant increase in size and angularity of clasts/lenses.

\section{FAULT CORE VARIABILITY}

251 Not every unit is laterally continuous along-strike, and each fault core unit varies in thickness over

252 different length scales (Fig. 6, Fig. 7). Observations from the six structural logs reveal the total thickness of 253 the fault core varies from 2.95 to $10.7 \mathrm{~m}$ over an along-strike distance of $560 \mathrm{~m}$ (Fig. 6). Every unit is 254 internally variable. For example, the green gouge is only observed in Log 4 and is $0.3 \mathrm{~m}$ wide. The blue 
gouge is continuous along-strike and varies from 0.65 to $2.65 \mathrm{~m}$ thick over $560 \mathrm{~m}$. The red foliated chaotic breccia is continuous along-strike and varies from 1.5 to $5.4 \mathrm{~m}$ thick. The red crackle breccia is only present between Logs 5 and 6 so varies in thickness from 0 to $4.65 \mathrm{~m}$.

Mapping of the fault core at Garron Point between Logs 5 and 6 reveals the smaller, meter-scale variability over an along-strike section of $50 \mathrm{~m}$ (Fig. 7). Over this $50 \mathrm{~m}$ section, the blue gouge varies from 0.7 to $2.6 \mathrm{~m}$ thick with a mean of $1.1 \pm 0.7 \mathrm{~m}(\mathrm{n}=20)$. The red foliated chaotic breccia varies from 2.3 to $5.4 \mathrm{~m}$ thick with a mean of $4.1 \pm 0.8 \mathrm{~m}(n=20)$. The red crackle breccia varies from 0.35 to $4.65 \mathrm{~m}$ thick with a mean of $2.6 \pm 1.5 \mathrm{~m}(\mathrm{n}=20)$. These observations demonstrate that, in addition to the smaller, centimetre-scale variability in each unit (Fig. 4), the total thickness of the fault core, and each unit within the fault core, can vary considerably over relatively short distances of $50 \mathrm{~m}$.

\section{MINERALOGY}

XRD results are summarised in Fig. 8. Surrounding the fault core are damage zones of contrasting mineralogy: the Fe-, Mg- and Ca-rich ferromagnesian serpentinites of the Highland Border Ophiolite to the south from K- and Al-rich quartzo-feldspathic crustal rocks of the Dalradian to the north. The Highland Border Ophiolite in the footwall damage zone is characterised by two mineralogically-distinct units. Ophicarbonate (footwall damage zone 1 ) is characterised by serpentinite (lizardite polymorph), carbonate (primarily dolomite) and quartz, despite serpentinite and quartz not commonly co-existing (although see (lizardite polymorph), calcite, dolomite, and silicates such as chlorite, prehnite, wollastonite, tremolite, talc and diopside (see Frost \& Beard, 2007). The hangingwall damage zone units are characterised by quartz and K- and Al-rich felsic minerals such as white mica and feldspar, presumably derived from the

278 Dalradian. Chlorite and biotite are also present indicative of low-grade, greenschist facies metamorphism supporting previous studies on the Dalradian (e.g., Vorhie and Ague, 2011). 
281 The whole rock (Fig. 9a) and the fine grained ( $<2 \mu \mathrm{m}$ fraction; Fig. 9b) mineral assemblages of the three fault core units demonstrate variable clay content as summarised in Table 1 and Table 2. Bulk mineralogy of the green gouge (FC 1a) is comprised of 48.8 weight $\%$ (wt\%) clay ( $24.3 w t \%$ illite + mica, $1.4 w t \%$ mixed layer illite-smectite (I-S) and $23.1 \%$ chlorite), with additional quartz, dolomite and anatase. The mixed layer illite-smectite and chlorite clays expand whereas illite does not. The $<2 \mu \mathrm{m}$ fraction suggests the clay minerals are poorly to moderately crystallised and Fe-rich (Table 2). Similarly, the blue gouge (FC 1 ) is comprised of $45.3 \mathrm{wt} \%$ clay (15.6 wt\% illite + mica, $6.1 \mathrm{wt} \% \mathrm{I}-\mathrm{S}$ and $23.6 \%$ chlorite), with additional quartz, dolomite and anatase. Despite comparable mineralogy, subtle differences exist between the green and blue gouge units. For example, the blue gouge is finer-grained with a higher $\%$ of the $<2 \mu \mathrm{m}$ fraction and contains more mixed layer illite-smectite and dolomite.

The red foliated chaotic breccia (FC 2) is comprised of $37.5 \mathrm{wt} \%$ clay (23.6 wt\% illite + mica, $5.6 \mathrm{wt} \% \mathrm{I}-\mathrm{S}$ and $8.1 \%$ kaolinite), with additional phases of quartz, dolomite, hematite and anatase. Compared to the blue gouge, the red foliated chaotic breccia contains non-swelling clays such as kaolinite and illite, chlorite is absent and has a higher percentage of quartz. The $<2 \mu \mathrm{m}$ fraction suggests the clay minerals within the red foliated chaotic breccia are moderately to well-crystallised (Table 2). In addition to a change in colour and structure, a distinct mineralogical change therefore occurs between the blue gouge and red foliated chaotic breccia. In the $<2 \mu \mathrm{m}$ fraction (Table 2 ), the green and blue gouge are comprised primarily of chlorite, which is Fe- and Mg-rich. Whereas, the red foliated chaotic breccia is comprised primarily of kaolinite and illite assemblages, which are $\mathrm{K}$ - and Al-rich.

Optical microscopy reveals the presence of microfossils within the clay-rich fault core (Fig. 10). These include relatively intact fragments of ancient bryozoans, possibly belonging to the order Fenestrata (as 
305 Both primary fabrics and secondary recrystallisation/growth textures are observed. Despite the fossils

306 being preserved within a high-strain fault gouge, there is no evidence of internal strain (e.g.,

307 microfracturing or shear indicators) within the fossil fragments.

\section{DISCUSSION}

Origin of the Clay-rich Fault Core

311 The mineralogical composition of the fault core matches the wall rocks. From the distinct chemical change

312 between the blue gouge and red foliated chaotic breccia, it can be assumed the Mg- and Fe-rich green and

313 blue gouges are chemically derived from the Mg- and Fe-rich Highland Border Ophiolite serpentinite wall

314 rocks (footwall damage zone 1 and 2). In contrast, the $\mathrm{K}$ - and Al-rich red foliated chaotic breccia is

315 chemically derived from the quartzo-feldspathic Dalradian wall rocks. These units remain surprisingly

316 unmixed: there are a limited number of clasts of weathered host rock within the clay units, but there are

317 no clasts of one clay unit within another that would be indicative of mixing. Similarly to other plate

318 boundary settings where serpentinite and quartzo-feldspathic wall rocks juxtapose (e.g., Moore and

319 Rymer, 2012), the HBF clay likely formed through fluid-assisted, shear-enhanced chemical reactions

320 between wall rocks of contrasting chemistry (the serpentinite of the Highland Border Ophiolite provides

321 the $\mathrm{Mg}$ and $\mathrm{Fe}$, while the Dalradian provides $\mathrm{K}, \mathrm{Al}$ and some of the $\mathrm{Si}$ ). The green gouge is only observed at one location (Log 4; Fig. 6) so could either represent a zone of localised alteration, or a remnant fragment of a reworked, previously extensive, fault core lithology. The blue gouge and red foliated chaotic breccia are continuous along-strike, albeit varying in thickness, suggesting that for this $560 \mathrm{~m}$ along-strike section, there has been continuous processing of both wall rocks. It remains unclear why the red crackle breccia is not laterally continuous along-strike. However, this may be controlled by the rheological variation within the Dalradian or by stress heterogeneities along the fault. 
329 The mineralogical composition of the clays provides constraints on the temperature of clay authigenesis.

330 With increasing temperatures, smectite transforms to illite. The reaction is complete by $\sim 120-150^{\circ} \mathrm{C}$,

331 which suggests an increasing proportion of illite within mixed layer illite-smectite with increasing temperature and depth (e.g., Hower et al. 1976; Vrolijk 1990). Hower et al. (1976), show that the degree of smectite transformation to illite can be used to gauge temperature. In all observed HBF fault core units, the smectite to illite reaction has progressed to $70-80 \%$ illite (Table 2 ) equating to a reaction temperature of 100 and $110^{\circ} \mathrm{C}$, corresponding to $<3 \mathrm{~km}$ depth ( $\left.<1 \mathrm{kbar}\right)$ assuming a high geothermal gradient setting. Mineral assemblages of chlorite, illite, smectite, kaolinite, as well as serpentinite and talc have been associated with fluid flow and brittle deformation under low temperature conditions $\left(\sim 100^{\circ} \mathrm{C}\right)$ at other plate boundary settings where the clays have formed through strike-slip deformation (e.g., the San Andreas fault; Moore and Rymer, 2007; Schleicher et al., 2009).

341 The low temperatures of formation of the clay $\left(\sim 100^{\circ} \mathrm{C}\right.$, palaeodepth of $\left.\sim 3 \mathrm{~km}\right)$ implies that this clay-rich fault core must form late in the evolution of the HBF as such a shallow formation depth would mean it would likely have been exhumed if it formed earlier. Based on the kinematics in the footwall damage zone

344 (Fig. 2c) and field-scale observations of the clay (e.g., fault-parallel foliations, incorporation of orientated wall rocks clasts, foliations wrapping around clasts, elongation of the clasts parallel to the HBF and the smectite-illite mineralogy) (Fig. 4, 5, Table 2) we propose the clay has a syn-faulting origin and formed as a result of shallow, low temperature, shear-enhanced chemical reactions between wall rocks of contrasting chemistry during latest sinistral strike-slip motion of the HBF. Unfortunately, there are no clear field-scale kinematic indicators within the clay that would help to constrain the kinematics either to motion in the

351 Andersen et al. 1999). 
353 Since the strike-slip faults (i.e. Reidel shears) offset previously deformed units of the Highland Border

354 Ophiolite (Fig. 2), clay authigenesis must be younger than the emplacement and deformation in the Highland Border Ophiolite and associated reverse motion on the HBF. Based on palaeomagnetic results, Elmore et al. (2002) suggest the dolomitisation of serpentinite in footwall damage zone 1 occurred in the Permian at 260 Mya. Clay growth must also be younger than the fossils, which assuming the bryozoans belong to the order Fenestrata (as identified by P. D. Taylor, pers. comm. 2018), are Ordovician to Permian in age. The presence of these ancient fossils within the clay therefore constrains the age of clay authigenesis to younger than Ordovician-Permian. To our knowledge this is the first time that the age of fossils preserved within a fault gouge have been used to constrain the relative age of that fault. Further microstructural and isotopic analyses (e.g., ${ }^{40} \mathrm{Ar}-{ }^{39} \mathrm{Ar}$ radiometric dating) are needed to fully constrain the absolute timing and nature of fluids controlling clay authigenesis and slip behaviour on this plate boundary fault. Both wall rocks are incorporated into the fault zone through chemical and mechanical alteration spanning the entire range of chemical and physical processes responsible for grain size reduction and wall rock comminution in a fault zone. In addition, the preservation of fragile fossils within the clay suggests strain within the units remain highly localised despite the fault having accumulated between $30-100 \mathrm{~km}$ of lateral offset (the exact magnitude of slip is debated in the literature). From the preservation of the textures in the clay, and the remarkable preservation of delicate fossil fragments it is clear that strain localisation by grain size reduction is principally concentrated on the margins of the fault core.

\section{How representative is the HBF of Active Plate Boundary Faults?}

375 The rocks on either side of the HBF are similar lithologies to those cut by the \$25M SAFOD (San Andreas

376 Fault Observatory at Depth) drilling project through creeping sections of the strike-slip San Andreas fault 377 (SAF). SAFOD drill core revealed the presence of a clay gouge $2.6 \mathrm{~m}$ thick (Bradbury et al. 2011). 
378 Comparable to the red foliated chaotic breccia of the HBF, the SAFOD clay is composed of a dark greyish-

379 black to greenish-black, highly-sheared, foliated matrix that wraps around centimetre-scale clasts of

380 serpentinite and sedimentary wall rocks that are elongate parallel to the foliation (Bradbury et al. 2011).

381 Structurally foliated fault rocks with clasts derived from the wall rocks are common along many strike-slip

382 plate boundary faults (e.g., Faulkner et al. 2003; Barth et al. 2013). The SAFOD clays have been interpreted as the product of fluid-assisted, shear-enhanced, metasomatic reactions between serpentinite, tectonically emplaced from a source in the Coastal Range Ophiolite (cf. the HBO), and quartzo-feldspathic crustal wall rocks (cf. the Dalradian) of contrasting chemistry (Bradbury et al. 2011; Moore \& Rymer 2012).

Laboratory friction experiments involving SAFOD gouge at hydrothermal conditions (temperature $\geq$ $200^{\circ} \mathrm{C}$ ) have demonstrated that due to the chemical contrast between the rock types, aseismic slip (creep) is initiated as soon as serpentinite and quartzo-feldspathic crustal rocks are sheared against each other

391 (Moore and Lockner, 2013). This is attributed to a solution transfer process, modifying the chemistry of the pore fluids within serpentinite, thereby promoting creep along serpentinite-bearing crustal faults at otherwise seismogenic depths (Moore and Lockner, 2013). Long-term shearing of these two chemically different rocks results in the authigenesis of mechanically weak minerals such as clay and talc, considered important in the mechanical behaviour of a fault. Laboratory experiments on the mechanical properties of clay mixtures suggest they would locally promote creep rather than stick-slip (i.e., the clay would retard fault rupture propagation and act as a barrier to earthquake propagation) (Scholz 1998; Ikari et al. 2009; Behnsen \& Faulkner 2012). These comparable observations on the SAFOD gouge may have implications for understanding palaeo-slip behaviour and clay authigenesis at the Stonehaven section of the HBF. 
402 By necessity, drilling projects at active plate boundary faults such as the SAFOD and the Japan Trench

403 Drilling Project, effectively sample one only or two transects across a fault, limiting the ability to capture 404 along-strike variability in fault zone properties. Whilst along-strike variability is commonly observed on 405 small-scale faults (e.g., Sosio De Rosa et al. 2018), our field observations demonstrate that seismogenic 406 plate boundary faults can also vary in thickness, structure and composition along-strike over different 407 length scales (Fig. 6, 7). This variability effect will likely be larger down-dip for strike-slip boundaries as 408 fault geometrical variability is smoothed in the direction parallel to slip (Sagy et al. 2007).

410 Plate boundaries are bi-material interfaces bringing together materials of different mechanical and 411 chemical properties (e.g., the Highland Border Ophiolite and Dalradian). However, studies that investigate 412 rupture propagation at plate boundaries typically assume constant fault properties along-strike and down413 dip (e.g., Cochard \& Rice 2000; Aochi \& Madariaga 2003; Shi \& Ben-Zion 2006; Ampuero \& Ben-Zion 414 2008). Structural and compositional fault properties spatially impact how and where earthquakes rupture, 415 nucleate and propagate (e.g., Aochi \& Madariaga 2003; Heermance et al. 2003; Wibberley et al. 2008; 416 Kirkpatrick \& Shipton 2009). Dynamic weakening processes and energy loss during earthquake slip is 417 dependent on the physical properties of the fault core (Shipton et al. 2006; Kirkpatrick \& Shipton 2009). 418 Kirkpatrick et al. (2018), demonstrated that due to the along-strike variation in slip zone thickness, slip419 weakening mechanisms such as thermal pressurisation must have been spatially variable during seismic 420 slip. Most slip-weakening mechanisms are triggered by frictional heating. Therefore, if the units within the 421 fault core have variable thickness, then the heating effect and consequently the lubrication effect that 422 determines the size of the rupture, will also be variable (the thinner the unit the faster the heating) 423 (Kirkpatrick et al. 2018). Along-strike thickness variations is expected to be a common feature of all faults

424 (Kirkpatrick et al. 2018). Therefore, earthquake models for seismogenic plate boundaries must consider, 425 or else assess tolerance and sensitivity to, along-strike variation in the thickness of units within the fault 426 core, as well as the composition (e.g., the localised green gouge in Log 4). 


\section{CONCLUSION}

428 This study delivers a level of detail on the along-strike internal fault core structure of a major plate

429 boundary fault that has rarely been seen before. The well-exposed Stonehaven section of the Highland

430 Boundary fault core is composed of four structurally and chemically distinct clay-rich units. Field and

431 mineralogical observations suggest clay authigenesis occurred as a result of shallow, low temperature,

432 shear-enhanced chemical reactions between wall rocks of contrasting chemistry during sinistral strike-slip

433 motion of the HBF.

434

435 The internal structure and mineralogy of the Highland Boundary fault is comparable to other major weak-

436 cored segments of plate boundary faults (e.g., the creeping section of the San Andreas fault in California).

437 Whilst along-strike variability is commonly observed on small-scale faults, our field observations

438 demonstrate that the core of seismogenic plate boundary faults can also vary in thickness and

439 composition along-strike over centimeter and meter length scales. Earthquake rupture mechanics

440 critically depend on the physical properties of fault rock assemblages. Therefore, models that investigate

441 rupture propagation at active plate boundaries should incorporate, or else assess tolerance and sensitivity

442 to, variable fault core thickness, structure and composition.

443

\section{ACKNOWLEDGEMENTS}

445 We thank Scottish Natural Heritage and local landowners for permission to sample at this Site of Special

446 Scientific Interest. All sample collection was conducted according to principles of geoconservation. The

447 paper benefitted from reviews by David Chew and an anonymous reviewer. All data underpinning this

448 publication will be available from the University of Strathclyde KnowledgeBase at

449 http://doi.org/10.15129/b515022c-c81e-4a62-acf7-c90f97bd42d6 from 01/07/2020 onwards, following

450 the cessation of an embargo period. Further details relating to the data and the embargo can be accessed

451 from the KnowledgeBase. 
FUNDING

454 This work is funded by an Environmental and Physical Science Research Council (EPSRC) Doctoral Training 455 Partnership (DTP) award (LM). TDR was supported initially by a grant from the Carnegie Foundation.

456

457

\section{REFERENCES}

458

Ampuero, J.-P. \& Ben-Zion, Y. 2008. Cracks, pulses and macroscopic asymmetry of dynamic rupture on a bimaterial interface with velocity-weakening friction. Geophysical Journal International, 173, 674692, https://doi.org/10.1111/j.1365-246X.2008.03736.x.

461

Andersen, T.B., Torsvik, T.H., Eide, E.A., Osmundsen, P.T. \& Faleide, J.I. 1999. Permian and Mesozoic extensional faulting within the Caledonides of central south Norway. Journal of the Geological Society, 156, 1073-1080, https://doi.org/10.1144/gsjgs.156.6.1073.

Aochi, H. \& Madariaga, R. 2003. The 1999 Izmit, Turkey, earthquake: Nonplanar fault structure, dynamic rupture process, and strong ground motion. Bulletin of the Seismological Society of America, 93, 1249-1266, https://doi.org/10.1785/0120020167.

Barth, N.C., Boulton, C., Carpenter, B.M., Batt, G.E. \& Toy, V.G. 2013. Slip localization on the southern Alpine Fault New Zealand. Tectonics, 32, 620-640, https://doi.org/10.1002/tect.20041.

Behnsen, J. \& Faulkner, D.R. 2012. The effect of mineralogy and effective normal stress on frictional strength of sheet silicates. Journal of Structural Geology, 42, 49-61, https://doi.org/10.1016/j.jsg.2012.06.015.

Bradbury, K.K., Evans, J.P., Chester, J.S., Chester, F.M. \& Kirschner, D.L. 2011. Lithology and internal structure of the San Andreas fault at depth based on characterization of Phase 3 whole-rock core in the San Andreas Fault Observatory at Depth (SAFOD) borehole. Earth and Planetary Science Letters, 310, 131-144, https://doi.org/10.1016/j.epsl.2011.07.020.

Caine, J.S., Evans, J.P. \& Forster, C.B. 1996. Fault zone architecture and permeability structure. Geology, 
24, 1025-1028, https://doi.org/10.1130/0091-7613(1996)024<1025.

478 Cawood, P.A., Merle, R.E., Strachan, R.A. \& Tanner, P.W.G. 2012. Provenance of the Highland Border Complex: constraints on Laurentian margin accretion in the Scottish Caledonides. Journal of the Geological Society London, 169, 575-586, https://doi.org/10.1144/0016-76492011-076.

Chester, F.M. \& Logan, J.M. 1986. Implications for mechanical properties of brittle faults from observations of the Punchbowl fault zone, California. Pure and Applied Geophysics, 124, 79-106, https://doi.org/10.1007/BF00875720.

Chester, F.M., Evans, J.P. \& Biegel, R.L. 1993. Internal Structure and Weakening Mechanisms of the San Andreas Fault. Journal of Geophysical Research, 98, 771-786.

Chew, D.M. 2003. Structural and stratigraphic relationships across the continuation of the Highland Boundary Fault in western Ireland. Geological Magazine, 140, 73-85, https://doi.org/10.1017/s0016756802007008.

Chew, D.M. \& Stillman, C.J. 2009. Late Caledonian orogeny and magmatism. In: Holland, C. H. \& Sanders, I. . (eds) The Geology of Ireland. Edinburgh, Dunedin Academic Press, 143-173.

Chew, D.M. \& Strachan, R.A. 2014. The Laurentian Caledonides of Scotland and Ireland. In: Corfu, F., Gasser, D. \& Chew, D. M. (eds) New Perspectives on the Caledonides of Scandinavia and Related Areas. Geological Society London, Special Publications, 390, 45-91.,

Chew, D.M., Daly, J.S., Magna, T., Page, L.M., Kirkland, C.L., Whitehouse, M.J. \& Lam, R. 2010. Timing of 496 ophiolite obduction in the Grampian orogen. Bulletin of the Geological Society of America, 122, 1787-1799, https://doi.org/10.1130/B30139.1.

Cochard, A. \& Rice, J.R. 2000. Fault rupture between dissimilar materials: Ill-posedness, regularization, and slip-pulse response. Journal of Geophysical Research, 105, 25891-25907, https://doi.org/10.1029/2000JB900230.

Cohee, B.P. \& Beroza, G.C. 1994. Slip Distribution of the 1992 Landers Earthquake and Its Implications for 
503 Dewey, J.F. \& Strachan, R.A. 2003. Changing Silurian - Devonian relative plate motion in the Caledonides : sinistral transpression to sinistral transtension. Journal of the Geological Society London, 160, 219229, https://doi.org/10.1144/0016-764902-085.

Dilek, Y. \& Furnes, H. 2014. Ophiolites and their origins. Elements, 10, 93-100, https://doi.org/10.2113/gselements.10.2.93. Palaeomagnetic dating of fluid-flow events in dolomitized rocks along the Highland Boundary Fault, central Scotland. Geofluids, 2, 299-314, https://doi.org/10.1046/j.1468-8123.2002.00045.x.

Faulkner, D.R., Lewis, A.C. \& Rutter, E.H. 2003. On the internal structure and mechanics of large strike-slip fault zones: Field observations of the Carboneras fault in southeastern Spain. Tectonophysics, 367,

Faulkner, D.R., Jackson, C.A.L., Lunn, R.J., Schlische, R.W., Shipton, Z.K., Wibberley, C.A.J. \& Withjack, M.O. 235-251, https://doi.org/10.1016/S0040-1951(03)00134-3. 2010. A review of recent developments concerning the structure, mechanics and fluid flow properties of fault zones. Journal of Structural Geology, 32, 1557-1575,

Frost, B.R. \& Beard, J.S. 2007. On Silica Activity and Serpentinization. Journal of Petrology, 48, 1351-1368, https://doi.org/10.1093/petrology/egm021.

Heermance, R., Shipton, Z.K. \& Evans, J.P. 2003. Fault structure control on fault slip and ground motion during the 1999 rupture of the Chelungpu fault, Taiwan. Bulletin of the Seismological Society of America, 93, 1034-1050, https://doi.org/10.1785/0120010230.

Henderson, W.G., Tanner, P.W.G. \& Strachan, R.A. 2009. The Highland Border Ophiolite of Scotland; observations from the Highland workshop field excursion of April 2008. Scottish Journal of Geology, 45, 13-18, https://doi.org/10.1144/0036-9276/01-381.

Hower, J., V. Eslinger, E., Hower, M.E. \& Perry, E.A. 1976. Mechanism of burial metamorphism of 
argillaceous sediment: Mineralogical and chemical evidence. GSA Bulletin, 87, 725-737.

528 Ikari, M.J., Saffer, D.M. \& Marone, C. 2009. Frictional and hydrologic properties of clay-rich fault gouge.

529 Journal of Geophysical Research: Solid Earth, 114, 1-18, https://doi.org/10.1029/2008JB006089.

530 Ikin, N.P. 1983. Petrochemistry and tectonic significance of the Highland Border Suite mafic rocks. Journal

531 of the Geological Society London, 140, 267-278, https://doi.org/10.1144/gsjgs.140.2.0267.

Kirkpatrick, J.D. \& Shipton, Z.K. 2009. Geologic evidence for multiple slip weakening mechanisms during seismic slip in crystalline rock. Journal of Geophysical Research, 114, 1-14, https://doi.org/10.1029/2008JB006037.

Kirkpatrick, J.D., Shipton, Z.K., Evans, J.P., Micklethwaite, S., Lim, S.J. \& McKillop, P. 2008. Strike-Slip Fault

Kirkpatrick, J.D., Rowe, C.D., et al. 2015. Structure and lithology of the Japan Trench subduction plate boundary fault. Tectonics, 34, 53-69, https://doi.org/10.1002/2014TC003695.

Kirkpatrick, J.D., Shervais, K.A.H. \& Ronayne, M.J. 2018. Spatial Variation in the Slip Zone Thickness of a Seismogenic Fault. Geophysical Research Letters, 45, 7542-7550, https://doi.org/10.1029/2018GL078767.

Lawther, S.E.M., Dempster, T.J., Shipton, Z.K. \& Boyce, A.J. 2016. Effective crustal permeability controls fault evolution: An integrated structural, mineralogical and isotopic study in granitic gneiss, Monte Rosa, northern Italy. Tectonophysics, 690, 160-173, https://doi.org/10.1016/j.tecto.2016.07.010. additional evidence and possible causes. Journal of the Geological Society London, 170, 403-415,

\section{Leslie, A.G. 2009. Border skirmish. Geoscientist, 19, 17-19.}

551 Lin, A., Ouchi, T., Chen, A. \& Maruyama, T. 2001. Co-seismic displacements, folding and shortening 
structures along the Chelungpu surface rupture zone occurred during the 1999 Chi-Chi (Taiwan) earthquake. Tectonophysics, 330, 225-244.

554 Ma, K.-F., Brodsky, E.E., Mori, J., Ji, C., Song, T.-R.A. \& Kanamori, H. 2003. Evidence for fault lubrication

555 during the 1999 Chi-Chi, Taiwan, earthquake (Mw7.6). Geophysical Research Letters, 30, 1-4,

$556 \quad$ https://doi.org/10.1029/2002GL015380.

557

Madariaga, R., Ampuero, J.P. \& Adda-Bedia, M. 2006. Seismic Radiation From Simple Models of Earthquakes. In: Abercrombie, R., McGarr, A., Di Toro, G. \& Kanamori, H. (eds) Earthquakes: Radiated Energy and the Physics of Faulting, Geophysical Monograph Series 170. American Geophysical Monograph Series, 223-236., https://doi.org/10.1029/170GM23.

McCarthy, W., Reavy, R., Stevenson, C. \& Petronis, M. 2015. Late Caledonian transpression and the structural controls on pluton construction; new insights from the Omey Pluton, western Ireland. Earth and Environmental Science Transactions Of The Royal Society Of Edinburgh, 106, 11-28, https://doi.org/10.1017/S1755691015000201.

Mendum, J.R. \& Noble, S.R. 2010. Mid-Devonian sinistral transpressional movements on the Great Glen Fault: the rise of the Rosemarkie Inlier and the Acadian Event in Scotland. In: Law, R. D., Butler, R. W. ., Holdsworth, R. E., Krabbendam, M. \& Strachan, R. A. (eds) Continental Tectonics and Mountain Building: The Legacy of Peach and Horne. Geological Society London, Special Publications, 335, 161187., https://doi.org/10.1144/SP335.8.

Monaghan, A.A. 2014. The Carboniferous shales of the Midland Valley of Scotland: geology and resource estimation. British Geological Survey for Department of Energy and Climate Change, London, UK.

Moore, D.E. \& Lockner, D.A. 2013. Chemical controls on fault behavior: Weakening of serpentinite sheared against quartz-bearing rocks and its significance for fault creep in the San Andreas system. Journal of Geophysical Research: Solid Earth, 118, 1-13, https://doi.org/10.1002/jgrb.50140.

Moore, D.E. \& Rymer, M.J. 2007. Talc-bearing serpentinite and the creeping section of the San Andreas fault. Nature, 448, 795-797, https://doi.org/10.1038/nature06064. 
577 Moore, D.E. \& Rymer, M.J. 2012. Correlation of clayey gouge in a surface exposure of serpentinite in the

578 San Andreas Fault with gouge from the San Andreas Fault Observatory at Depth (SAFOD). Journal of 579 Structural Geology, 38, 51-60, https://doi.org/10.1016/j.jsg.2011.11.014.

580 Moore, D.M. \& Reynolds, R.C. 1997. X-Ray Diffraction and the Indentification and Analysis of Clay $581 \quad$ Minerals. Oxford, Oxford University Press.

Parnell, J., Baron, M. \& Boyce, A. 2000. Controls on kaolinite and dickite distribution, Highland Boundary Fault Zone, Scotland and Northern Ireland. Journal of the Geological Society London, 157, 635-640, https://doi.org/10.1144/jgs.157.3.635.

Ramsay, D.M. 1962. The Highland Boundary Fault, reverse or wrench fault? Nature, 195, 1190-1191.

Sagy, A., Brodsky, E.E. \& Axen, G.J. 2007. Evolution of fault-surface roughness with slip. Geology, https://doi.org/10.1130/G23235A.1.

Schleicher, A.M., Warr, L.N. \& Van Der Pluijm, B.A. 2009. On the origin of mixed-layered clay minerals from the San Andreas Fault at 2.5-3 km vertical depth (SAFOD drillhole at Parkfield, California). Contributions to Mineralogy and Petrology, 157, 173-187, https://doi.org/10.1007/s00410-008-

Scholz, C.H. 1998. Earthquakes and friction laws. Nature, 391, 37-42.

Shi, Z. \& Ben-Zion, Y. 2006. Dynamic rupture on a bimaterial interface governed by slip-weakening friction. Geophysical Journal International, 165, 469-484, https://doi.org/10.1111/j.1365-246X.2006.02853.x. Faults, Damage Zones, and the Seismic Energy Budget. In: Abercrombie, R., McGarr, A., Di Toro, G. \& Kanamori, H. (eds) Earthquakes: Radiated Energy and the Physics of Faulting, Geophysical Monograph Series 170. Washington D.C., American Geophyscial Union, 217-222.

Sosio De Rosa, S., Shipton, Z.K., Lunn, R.J., Kremer, Y. \& Murray, T. 2018. Along-strike fault core thickness variations of a fault in poorly lithified sediments, Miri (Malaysia). Journal of Structural Geology, 116, 189-206, https://doi.org/10.1016/j.jsg.2018.08.012. 
602

603

604

605

606

607

608

609

610

611

612

613

614

615

616

617

618

619

620

621

622

623

624

625

626

Streit, E., Kelemen, P. \& Eiler, J. 2012. Coexisting serpentine and quartz from carbonate-bearing serpentinized peridotite in the Samail Ophiolite, Oman. Contributions to Mineralogy and Petrology, 164, 821-837, https://doi.org/10.1007/s00410-012-0775-z.

Tanner, P.W.G. 2008. Tectonic significance of the Highland Boundary Fault, Scotland. Journal of the Geological Society London, 165, 915-921, https://doi.org/10.1144/0016-76492008-012.

Toy, V.G., Boulton, C.J., et al. 2015. Fault rock lithologies and architecture of the central Alpine fault, New Zealand, revealed by DFDP-1 drilling. Lithosphere, 7, 155-173, https://doi.org/10.1130/L395.1.

Ujiie, K. \& Kimura, G. 2014. Earthquake faulting in subduction zones: insights from fault rocks in accretionary prisms. Progress in Earth and Planetary Science, 1, 1-30, https://doi.org/10.1186/21974284-1-7.

Viete, D.R., Oliver, G.J.H., Fraser, G.L., Forster, M.A. \& Lister, G.S. 2013. Timing and heat sources for the Barrovian metamorphism, Scotland. Lithos, 177, 148-163, https://doi.org/10.1016/j.lithos.2013.06.009.

Vorhie, S.H. \& Ague, J.J. 2011. Pressure-temperature evolution and thermal regimes in the Barrovian zones, Scotland. Journal of the Geological Society London, 168, 1147-1166, https://doi.org/10.1144/0016-76492010-073.

Vrolijk, P. 1990. On the mechanical role of smectite in subduction zones. Geology, 18, 703-707.

Wibberley, C.A.J. \& Shimamoto, T. 2003. Internal structure and permeability of major strike-slip fault zones: The Median Tectonic Line in Mie Prefecture, Southwest Japan. Journal of Structural Geology, 25, 59-78, https://doi.org/10.1016/S0191-8141(02)00014-7.

Wibberley, C.A.J., Yielding, G. \& Di Toro, G. 2008. Recent advances in the understanding of fault zone internal structure: a review. In: Wibberley, C. A. J., Kurz, W., Imber, J., Holdsworth, R. E. \& Collettini (eds) Geological Society, London, Special Publications. 5-33., https://doi.org/10.1144/SP299.2.

Winchester, S. 2006. A Crack in the Edge of the World: The Great American Earthquake of 1906. London, UK, Penguin Books. 
627 Woodcock, N.H. \& Mort, K. 2008. Classification of fault breccias and related fault rocks. Geological

628 Magazine, 145, 435-440, https://doi.org/10.1017/S0016756808004883.

629 Yeh, E.C., Sone, H., et al. 2007. Core description and characteristics of fault zones from Hole-A of the

630 Taiwan Chelungpu-Fault Drilling Project. Terrestrial, Atmospheric and Oceanic Sciences, 18, 327-357,

631 https://doi.org/10.3319/TAO.2007.18.2.327(TCDP).

632

633 
634 Table 1. XRD results of the whole (bulk) rock fraction (5-10 $\mu \mathrm{m})$ from three clay-rich fault core units of the

635 HBF (FC1a: green gouge; FC1: blue gouge; FC 2: red foliated chaotic breccia). See Fig. 6 for sample

636 locations. Modal \% was determined via peak intensity quantification.

\begin{tabular}{|c|c|c|c|c|c|c|c|c|c|c|}
\hline Sample & $\begin{array}{l}\text { Illite/ } \\
\text { Smectite } \\
\text { (I-S) }\end{array}$ & $\begin{array}{l}\text { Illite } \\
+ \\
\text { Mica }\end{array}$ & Kaolinite & Chlorite & Qtz & $\begin{array}{l}\mathrm{K} \\
\text { Feldspar }\end{array}$ & Plagioclase & Dolomite & Anatase & Hematite \\
\hline FC 1a & 1.4 & 24.3 & 0 & 23.1 & 44.6 & TR & 0 & 3.3 & 3.3 & 0 \\
\hline $\mathrm{FC} 1$ & 6.1 & 15.6 & 0 & 23.6 & 41.4 & TR & 0 & 11.2 & 2.1 & TR \\
\hline $\mathrm{FC} 2$ & 5.6 & 23.8 & 8.1 & 0 & 57.7 & TR & TR & 1.7 & 0.4 & 2.7 \\
\hline
\end{tabular}

637

638 Table 2. XRD results of the fine-grained $<2 \mu \mathrm{m}$ fraction from three clay-rich fault core units of the HBF

639 (FC1a: green gouge; FC1: blue gouge; FC 2: red foliated chaotic breccia). See Fig. 6 for sample locations.

640 Modal \% was determined via peak intensity quantification.

\begin{tabular}{|c|c|c|c|c|c|c|c|c|c|c|c|c|c|}
\hline \multirow{2}{*}{ Sample } & \multirow{2}{*}{$\begin{array}{l}\text { Wt. \% } \\
<2 \mu \mathrm{m}\end{array}$} & \multicolumn{3}{|c|}{ Illite/smectite } & \multicolumn{2}{|c|}{ Illite } & \multicolumn{2}{|c|}{ Kaolinite } & \multicolumn{3}{|c|}{ Chlorite } & \multirow{2}{*}{$\begin{array}{c}\text { Qtz } \\
\%\end{array}$} & \multirow{2}{*}{$\begin{array}{c}\text { Dol } \\
\%\end{array}$} \\
\hline & & $\%$ & Order* & $\%$ illite & $\%$ & Crys & $\%$ & Crys $\dagger$ & $\%$ & Crys $†$ & $Y \ddagger$ & & \\
\hline FC 1a & 12.5 & 11.6 & 0 & $70-80$ & 25.2 & $P$ & 0 & & 45.4 & $M$ & 2 & 17.8 & 0 \\
\hline FC 1 & 51.1 & 11.9 & $\mathrm{O}$ & $70-80$ & 19.9 & P & 0 & & 46.1 & M & 2 & 13.5 & 8.5 \\
\hline $\mathrm{FC} 2$ & 19.6 & 28.7 & $\mathrm{O}$ & $70-80$ & 39 & $\mathrm{H}$ & 21.2 & M & 0 & & - & 11.1 & 0 \\
\hline
\end{tabular}

* Order: $\mathrm{O}=$ ordered interstratification

+ Clay crystallinity: $\mathrm{H}=$ highly crystalline; $\mathrm{M}=$ moderately crystalline; $\mathrm{P}=$ poorly crystalline

† $\mathrm{Y}=$ number of Fe atoms in six octahedral sites

641 
643 Fig. 1. Geological map of the HBF near Stonehaven, NE Scotland. (a) Simplified geological map of Scotland 644 indicating the location of the study site near Stonehaven. GT, Grampian Terrane; MVT, Midland Valley

645 Terrane; GGF, Great Glen fault; SUF, Southern Uplands fault. (b) The Highland Boundary fault along the coastal section $\sim 1 \mathrm{~km}$ north of Stonehaven. The location of the six structural logs are indicated.

647

648 Fig. 2. Damage zone deformation of the HBF. (a) Field photograph of the HBF at the northern end of 649 Craigeven Bay looking northeast [grid reference NO 8870 8740]. (b) Stereographic projection of poles to 650 Dalradian bedding showing the mean bedding planes and the interpreted fold axis (Kamb contours of 651 interval 2 sigma and confidence level 3). (c) Stereographic projection of field data on small faults 652 associated with the HBF consistent with strike-slip faulting. Poles to all faults in the Highland Border 653 Ophiolite and the mean planes of sinistral, dextral and thrust faults interpreted into a strike-slip strain 654 ellipse for sinistral motion of the HBF (separated based on kinematic markers in the field). Mean planes 655 were determined from contour maps. There are numerous faults where the sense of motion cannot be 656 determined (unfilled), however, they are not outliers and can be grouped into one of the three sets. The principal stress axes are inferred from kinematic data. (d) Ideal strike-slip strain ellipse for comparison assuming symmetry of the Reidel shears around a fault with the same dip as the HBF and pure strike-slip. All stereonet plots were created using Stereonet 10 software.

Fig. 3. Summarised fault zone structure. (a) Schematic structural log illustrating the units within the fault core $(\mathrm{FC})$ and footwall and hangingwall damage zones (FW DZ and HW DZ, respectively) of the HBF. The structural log schematically highlights the typical fabrics in each unit. The tick marks and other ornamentation within the units correspond to foliations. The \pm symbol indicates that the unit may or may not be present in all structural logs. (b) Shear zone in metabasalt lava sequence (footwall damage zone 3, FW DZ 3) [grid reference NO 388953 787474]. (c) Fractures with alteration halos in carbonated 
serpentinite (footwall damage zone 2, FW DZ 2) [grid reference NO 388939 787494]. (d) Multiphase

668 carbonate veining in ophicarbonate (footwall damage zone 1, FW DZ 1) [grid reference NO 388931

669 787496]. (e) Green gouge (fault core 1a, FC 1a) between ophicarbonate wall rock to the SE and the blue

670 gouge unit to the NW (Log 4 only) [grid reference NO 388914 787493]. (f) The contact between the blue

671 gouge (fault core 1, FC 1) and the red foliated chaotic breccia (fault core 2, FC 2) indicating localised

672 mixing [grid reference NO 389201 787640].

673

674 Fig. 4. Centimetre-scale variations in the fault core units. (a) Detailed sketch of the fault core from Log 4.

675 Clast sizes and foliation thicknesses are exaggerated (x2) for illustration purposes. The variation in clast

676 composition (colour) is also shown with sandier wall rock clasts depicted in yellow. (b) Rose diagram of

677 the foliations from the blue gouge (fault core 1) (all logs). (c) Rose diagram of the foliations from the red

678 foliated chaotic breccia (fault core 2) (all logs). (d) Rose diagram of the orientation of the long axis of the 679 clasts and lenses from both the red foliated chaotic breccia (fault core 2) and the red crackle breccia from 680 the fault core - hangingwall damage zone transition (all logs).

681

682 Fig. 5. Photographs and detailed sketches of the fault core units. The fault core clays were wet and sticky meaning that attempts to clean the outcrop resulted in smearing of the clays across the surface. The internal structure was therefore exposed by lifting out sections of the clay with a shovel-tip. This left an irregular surface that did not photograph well, but which could be logged and sampled in the field. (a)

686 Blue gouge (fault core 1). The indents in the photograph represent the spade marks from digging [grid reference NO 388914 787494]. (b) Red foliated chaotic breccia with clear structural fabrics (fault core 2)

688 [grid reference NO 388914 787495]. (c) Red crackle breccia with large, fragmented lenses of Dalradian in 689 the fault core - hangingwall damage zone transition zone [grid reference NO 389238 787664]. The 'clasts' 690 that are white are shingle. 
692 Fig. 6. Structural logs highlighting the along-strike variability in the thickness of the HBF fault core units 693 over the well-exposed $560 \mathrm{~m}$ Stonehaven section (refer to Fig. 1b for the location of each log). The 694 thickness of the fault core units is to the same scale (that on the left), whereas the horizontal axis is only 695 schematically to scale to indicate the approximate position along-strike of the structural logs beginning at $6960 \mathrm{~m}$ for Log 1 (significant across-fault exaggeration 25:1). Each log mapped a patchy shoreline with large boulders in places, thus the contacts between each unit are inferred by the dashed line. The Dalradian is a mix of polyphase metamorphic- and fault-related folding so the units are not correlated along-strike. Key as in Fig. 3. The stars in Log 4 represent the location of the fault core samples used for XRD analysis (Table 1; Table 2). Green gouge [grid reference NO 388914 787493]; blue gouge [grid reference NO 388914 787494]; red foliated chaotic breccia [grid reference NO 388914 787495].

702

Fig. 7. Smaller-scale structural logs at Garron Point highlighting the along-strike, metre-scale variability of the HBF fault core over a $50 \mathrm{~m}$ section (refer to Fig. $1 \mathrm{~b}$ and Fig. 6 for location). The horizontal and vertical axes are not to the same scale with significant across-fault exaggeration (5:1). The tick marks on the horizontal axis shows the density of mapping. Each log mapped a patchily exposed shoreline, thus the contacts between each unit are inferred by the dashed line. We have only mapped the exposure, thus the units between the logs are not inferred. Key as in Fig. 3 (the lithological variations in the Dalradian hangingwall are not shown). The red numbers refer to the dip of the faults bounding the fault core, while the grey 'lentils' represent the size and orientation of the Dalradian clasts/lenses. The clast size generally decreases away from the Dalradian with a concomitant increase in clay content. Boxplots highlight that each unit within the fault core varies in thickness over the $50 \mathrm{~m}$ section. The thick black line represents the median, while the cross represents the mean. The same length scale applies to all three boxplots.

Fig. 8. Summary schematic log of the HBF architecture with associated mineralogy determined via x-ray diffraction (XRD) analysis. The samples used for analysis were from Log 4 only [grid reference NO 388914 
717 787493]. The \pm symbol indicates that the unit may or may not be present depending on the location of

718 structural log. For the mineralogy of the metabasalt lava sequence (footwall damage zone 3) refer to Ikin 719 (1983).

720

721 Fig. 9. X-ray diffraction (XRD) diffractograms for (a) the whole (bulk) rock and (b) $<2 \mu \mathrm{m}$ size fractions of 722 the three clay-rich fault core domains of the Highland Boundary Fault. I, Illite; I-S, Illite-Smectite; C,

723 Chlorite; K, Kaolinite; A, Anatase; Q, Quartz; D, Dolomite; H, Hematite. For the $<2 \mu$ m size fraction, the

724 diffractograms for the four clay treatments are overlain to identify the clay mineral assemblages present.

725

726 Fig. 10. Fault zone palaeontology - shallow marine microfossils in the blue gouge. (a) Fan-shaped,

727 bryozoan, possibly of the Fenestrata order displaying both primary and secondary recrystallisation

728 textures. (b) A bryozoan and echinoid spine. (c) Fan-shaped, bryozoan, possibly of the Fenestrata order.

729 All images are in cross-polarised light (XPL). 